\title{
Soccer ball related posterior segment closed-globe injuries in outdoor amateur players
}

\author{
Amatör oyuncularda futbol topu ile oluşan \\ arka segment kapalı göz yaralanmaları \\ Gökçen GÖKÇE, ${ }^{1}$ Osman Melih CEYLAN, ${ }^{2}$ Fazil Cüneyt ERDURMAN, ${ }^{2}$ \\ Ali Hakan DURUKAN, ${ }^{2}$ Güngör SOBACI ${ }^{2}$
}

\section{BACKGROUND}

The aim of this study is to report the characteristics, treatment, and anatomical and functional outcomes of outdoor amateur soccer players with soccer ball-related posterior segment ocular trauma.

\section{METHODS}

We conducted a retrospective chart review of 22 patients with diagnoses of closed-globe ocular trauma caused by soccer play activity from 2004 through 2008. Injuries were classified according to Ocular Trauma Classification.

\section{RESULTS}

All patients $(\mathrm{n}=22)$ were male, and all injuries were caused by contact with the soccer ball itself. Sixteen (72\%) patients did not require any treatment. Surgery was performed on $5(22 \%)$ patients. Twenty (91\%) patients had $5 / 200$ or better visual acuity (VA) at presentation and $2(9 \%)$ had hand movements or worse VA. At the final visit, all patients had $5 / 200$ or better VA $(\mathrm{p}<0.01)$.

\section{CONCLUSION}

A soccer ball can cause significant posterior segment trauma, and using eye protection equipment might be an appropriate solution.

Key Words: Closed-globe trauma; contusion; protection; soccer.

\section{AMAÇ}

Çalışmamızın amacı amatör oyuncularda futbol topu ile oluşan arka segment kapalı göz yaralanmalarının anatomik ve fonksiyonel sonuçlarını ve uygulanan tedavileri incelemektir.

\section{GEREÇ VE YÖNTEM}

2004-2008 yılları arasında futbol oynarken kapalı göz yaralanması geçiren 22 hastanın kayıtları geriye dönük olarak incelendi. Yaralanmalar okuler travma sinıflamasına göre değerlendirildi.

\section{BULGULAR}

Yirmi iki hastanın tümü erkekti ve yaralanmaların tümü futbol topu çarpmasına bağlıydı. On altı (\%72) hastaya herhangi bir tedavi uygulanmadi. Beş (\%22) hastaya cerrahi tedavi uygulandı. Yirmi (\%91) hastanın başvuru anındaki görme keskinliği 5/200 ve üzerindeyken iki (\%9) hastanın ise el hareketi ve altındaydı. Son kontrol muayenesinde 22 hastanın tümünde $5 / 200$ ve üzeri görme keskinlik düzeyi elde edildi $(\mathrm{p}<0,01)$.

\section{SONUÇ}

Futbol topu ciddi arka segment travmasina neden olabilmektedir ve koruyucu ekipman kullanımı uygun bir çözüm olabilir.

Anahtar Sözcükler: Kapal1 göz travması; kontüzyon; koruma; futbol.
Soccer is the most popular sport in the world and it is the leading cause of sport related ocular trauma. ${ }^{[1]}$ Soccer-related ocular injury is an important worldwide eye health problem because of the use of the unpro- tected head for controlling the ball. Injury can result from contact of the head with another head, ground, or the kicked ball.

The aim of this study is to report the characteris-
Presented at the 8th Congress of SEEOS meeting

(May 19-22, 2011, Istanbul, Turkey).

${ }^{1}$ Department of Ophthalmology, Sarikamis Military Hospital, Kars;

${ }^{2}$ Department of Ophthalmology Gulhane Military Medical Faculty,
8. SEEOS Kongresi'nde sunulmustur

(19-22 Mayis 2011, İstanbul).

${ }^{1}$ Sarıkamıș Asker Hastanesi, Göz Hastalıkları Kliniği, Kars; ${ }^{2}$ Gülhane Askeri Tıp Akademisi, Göz Hastalıkları Anabilim Dalı, Ankara. 
tics, treatments, and anatomical and functional outcomes of outdoor amateur soccer players with soccer ball-related posterior segment (zone 3) ocular trauma.

\section{MATERIALS AND METHODS}

This study was performed under an institutional ethics review board-approved protocol. We conducted a retrospective chart review of 22 patients admitted to the Department of Ophthalmology at the Gulhane Military Medical Academy (Ankara, Turkey) with diagnoses of closed-globe ocular trauma caused by a soccer ball from 2004 through 2008. All patients injured in soccer play underwent an initial evaluation. All interventions were performed at our department. Injuries resulting from head to head, head to upper or lower extremity, or head to ground or other surfaces were not included in the study. Patients with only ocular adnexal damage or minor ocular injuries such as corneal abrasions or corneal/conjunctival/scleral foreign bodies and patients with concomitant non-ocular injuries were not included in the study.

Ocular injuries were classified according to the criteria of the Ocular Trauma Classification Group (OTG) including: type of injury (only zone 3 injuries were included in this study, but additional zone 1 and 2injuries were also recorded), visual acuity (VA) at initial examination, the presence of relative afferent pupillary defect (RAPD), and zone of injury. ${ }^{[2]}$ The initial and final VA were categorized using the OTG grading system. Grade 1 was better than 20/40. Grade 2 was $20 / 50$ to $20 / 100$. Grade 3 was $19 / 100$ to $5 / 200$. Grade 4 was 4/200 to light perception. Grade 5 was no light perception. Final visual outcome was defined as poor if visual acuity was $<5 / 200$.

The pars plana vitrectomy (PPV) procedure was performed using standard 20-gauge three-port pars plana technique. A non-contact fundus observation system (EIBOS; Möller-Wedel GmbH, Wedel, Germany) was used for wide-angle viewing. In the presence of lens damage, PPV was combined with Lens aspiration. One thousand centistokes (cs) silicone oil was used for internal tamponade. Silicone oil was chosen based on the surgeon's preferences and the patient's retinal conditions.

Statistical analysis was performed using SPSS 15.0 for Windows (SPSS, Chicago, IL, USA). McNemar's tests were used to analyze before vs. after comparisons. Statistical significance was set at $\mathrm{p}<0.05$.

\section{RESULTS}

Patients $(\mathrm{n}=22)$ ranged in age from 13 to 32 years (mean age $21.8 \pm 4.0$ years) and were all male. All injuries were contusions caused by contact with a soc-

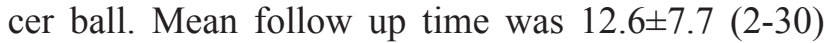
months. On initial ophthalmic examination, hyphema existed in $8(36 \%)$ patients, and commotio retinae was present in $8(36 \%)$. Macular edema was found in 5 $(22 \%)$ patients. One (4\%) subject presented with choroid rupture. Retinal detachment (with retinal tears) was found in $5(22 \%)$ patients. Retinal tears without detachment were found in 1 patient $(4 \%)$. Traumatic lens injury was observed in $4(18 \%)$ patients, one of which had lens subluxation. Vitreous hemorrhage was present in $11(50 \%)$ subjects. RAPD was documented in only $1(4 \%)$ patient. Sixteen $(72 \%)$ patients did not require any treatment. Surgery (including lens aspiration, buckle, vitrectomy, or their combination) was performed in $5(22 \%)$ patients. Twenty $(91 \%)$ patients had $5 / 200$ or better VA at presentation, and $2(9 \%)$ had hand movements or worse VA. At the final visit, all 22 patients had 5/200 or better VA $(\mathrm{p}<0.01)$. Postoperative PVR was observed in 2 patients that underwent vitreoretinal surgery. No postoperative vitreoretinal complication requiring additional vitreoretinal surgery was noted in any of the eyes that underwent PPV. Silicone oil was left as a permanent tamponade in an eye with severe PVR in case of subsequent hypotony and phthisis. Demographic features of the patients and interventions are listed in Table 1.

\section{DISCUSSION}

Closed-globe ocular trauma is a common result of sports-related injury. Although the integrity of the eye wall remains intact, contusion type trauma may cause serious posterior segment damage. ${ }^{[3]}$ Because of the popularity of soccer all over the world, serious eye injuries might be encountered any time. According to Larrison, hyphema was the most frequent symptom after soccer-related eye injury. ${ }^{[4]}$ Our study excluded isolated zone 1 and 2 contusion injuries. Vitreous hemorrhage was the posterior segment injury found in the highest percentage in our study $(50 \%)$. Firm attachments of the vitreoretinal base in young population probably are responsible for these haemorrhages.

The soccer ball is different from the other sports balls: orbital penetration is lower, but the time in the orbit is longer. ${ }^{[5]}$ So the characteristics of eye trauma caused by a soccer ball is different from other traumas and may be associated with severe ocular morbidity and visual impairment. Studies revealed that soccer ball penetration is not significantly related to the size of the ball. ${ }^{[5]}$ The impact-related energy causing ball molding to facial contours is more associated with penetration. The energy correlates with velocity. In a study, professional players kicked the ball at a mean velocity of $26.2 \mathrm{~m} / \mathrm{s}(58.6 \mathrm{mph})$ while amateurs kicked the ball at a mean velocity of $18.5 \mathrm{~m} / \mathrm{s}(41.4 \mathrm{mph})$. They both produced significant energy. ${ }^{[6]}$ According to Reed, the energy from the kicked ball is not enough to cause retinal haemorrhage. ${ }^{[7]}$ In contrast to this study, eight players $(36 \%)$ had retinal haemorrhages in our 
Table 1. Demographic features, ocular examinations of the patients and interventions

\begin{tabular}{|c|c|c|c|c|c|c|c|c|}
\hline No & Age & Eye & $\begin{array}{l}\text { Ocular } \\
\text { presentation }\end{array}$ & Treatment & $\begin{array}{l}\text { Follow up } \\
(\mathrm{m})\end{array}$ & $\begin{array}{l}\text { Initial } \\
\text { VA }\end{array}$ & $\begin{array}{l}\text { Final } \\
\text { VA }\end{array}$ & $\begin{array}{l}\text { Final examination } \\
\text { complication }\end{array}$ \\
\hline 1 & 21 & Right & $\mathrm{I}+\mathrm{VH}$ & No & 6 & 1 & 1 & I (small) \\
\hline 2 & 27 & Left & $\mathrm{VH}+\mathrm{RT}$ & LPC & 9 & 1 & 1 & No \\
\hline 3 & 30 & Left & $\mathrm{LI}+\mathrm{Co}$ & No & 12 & 1 & 1 & $\mathrm{Ca}$ \\
\hline 4 & 23 & Right & $\mathrm{RD}$ & PPV+Buckle & 24 & 2 & 2 & No \\
\hline 5 & 19 & Left & $\mathrm{H}+\mathrm{VH}$ & No & 8 & 2 & 1 & No \\
\hline 6 & 21 & Right & Co & No & 2 & 1 & 1 & No \\
\hline 7 & 26 & Right & $\mathrm{H}+\mathrm{VH}+\mathrm{RH}+\mathrm{Co}$ & No & 18 & 3 & 3 & MS \\
\hline 8 & 45 & Right & $\mathrm{H}+\mathrm{VH}$ & No & 6 & 1 & 1 & No \\
\hline 9 & 20 & Left & $\mathrm{H}+\mathrm{Co}$ & No & 3 & 1 & 1 & No \\
\hline 10 & 21 & Left & $\mathrm{H}+\mathrm{VH}+\mathrm{RT}+\mathrm{RD}$ & Buckle & 20 & 1 & 1 & No \\
\hline 11 & 13 & Left & $\mathrm{LI}+\mathrm{RD}$ & L.Asp+PPV+Silicone oil & 26 & 4 & 3 & PVR \\
\hline 12 & 21 & Right & $\mathrm{LI}+\mathrm{LS}+\mathrm{Co}$ & No (patient refused) & 12 & 2 & 2 & $\mathrm{Ca}+\mathrm{LS}$ \\
\hline 13 & 21 & Left & $\mathrm{RH}+\mathrm{ME}+\mathrm{Co}$ & No & 14 & 2 & 1 & No \\
\hline 14 & 17 & Right & $\mathrm{RH}+\mathrm{ME}+\mathrm{RD}$ & $\mathrm{PPV}+\mathrm{Gas}$ & 22 & 2 & 2 & No \\
\hline 15 & 21 & Right & $\mathrm{H}+\mathrm{VH}+\mathrm{Co}$ & No & 6 & 1 & 1 & No \\
\hline 16 & 21 & Right & $\mathrm{H}+\mathrm{RH}+\mathrm{Co}$ & No & 8 & 1 & 1 & No \\
\hline 17 & 20 & Right & $\mathrm{H}+\mathrm{VH}+\mathrm{RD}$ & $\mathrm{PPV}+\mathrm{Gas}+$ Buckle & 30 & 4 & 2 & PVR \\
\hline 18 & 21 & Left & $\mathrm{VH}+\mathrm{CR}+\mathrm{RH}+\mathrm{ME}$ & No & 13 & 2 & 2 & $\mathrm{CR}$ \\
\hline 19 & 21 & Left & $\mathrm{VH}+\mathrm{RH}$ & No & 9 & 1 & 1 & No \\
\hline 20 & 20 & Right & $\mathrm{I}+\mathrm{ME}$ & No & 8 & 2 & 2 & $\mathrm{I}+\mathrm{MS}$ \\
\hline 21 & 23 & Right & $\mathrm{LI}+\mathrm{RH}+\mathrm{ME}$ & No & 17 & 2 & 2 & $\mathrm{Ca}$ \\
\hline 22 & 21 & Left & $\mathrm{VH}+\mathrm{RH}$ & No & 6 & 1 & 1 & No \\
\hline
\end{tabular}

VA: Visual acuity; Ca: Cataract; Co: Commosio retina; H: Hyphema; I: Iridodialysis; VH: Vitreous hemorrhage; RH: Retinal hemorrhage; RD: Retinal detachment; RT: Retinal tear; ME: Macular edema; MS: Macular scar; No: No abnormality; CR: Choroid rupture; LS: Lens subluxation; PPV: Pars plana vitrectomy; LI: Lens injury, L.Asp: Lens aspiration; LPC: Laser photocoagulation; PVR: Proliferative vitreoretinopathy; m: Months.

study. Furthermore, we found that when the kicked ball hits the head and deforms significantly to fit facial contours, the energy is directly transmitted to the retina, resulting in tears. Retinal breaks are the most frequent diagnosis in follow up period. ${ }^{[8]}$ In most cases $(80 \%)$ retinal tears caused by soccer balls were associated with retinal detachment in our study, which may reveal that much more energy transmits to the retina than estimated. Although the injury is caused by inferotemporal contact with the ball in most cases (the frontal bone and nose usually make a protection from the impact coming from other directions ${ }^{[9]}$ ), it is essential to examine all the quadrants of peripheral retina.

Retinal detachment was the main indication for vitreoretinal surgery in three patients in our study. The development of PVR was the most frequent reason for poor visual outcome in patients with retinal detachment and was responsible for surgical failure. A sudden anteroposterior compression and the expansion of the eyeball perpendicular to the direction of impact has been proposed as the major cause of the contusion injuries. ${ }^{[5]}$ In all patients with ocular contusion, careful peripheral retinal examination with scleral depression should be performed irrespective of the presence of damage to the anterior segment. Otherwise, retinal breaks may remain unnoticed for years until the development of retinal detachment. ${ }^{[3]}$ However, in cases with vitreous hemorrhage from ocular trauma, this examination may not be possible and retinal damage may not be accurately and completely diagnosed. In such cases, B-mode ultrasonography is helpful for the assessment of the posterior segment. ${ }^{[10]}$

Choroidal rupture is a common finding in smaller ball traumas (paint ball, tennis, golf) rather than soccer-related ones and it was an unusual finding in our study. It was temporally located near macula, and resulted in poor visual outcome. This finding may reveal that orbital penetration secondary to soccer ball is deeper than estimated.

Some limitations in this study should be noted including its retrospective design. Additionally only males participated in our study. Gender differences that may be present within these injuries could not be analyzed. In our country, soccer is not popular among women, so this is the main source of this limitation. Another limitation of the study was the relatively short follow-up period; patients who underwent observation 
without treatment could not be evaluated in terms of long-term complications.

In our study we have identified that soccer can cause significant posterior segment trauma and using eye protection equipment according to ASTM standard F803 might be an appropriate solution for this important and frequent ophthalmologic problem.

Conflict-of-interest issues regarding the authorship or article: None declared.

\section{REFERENCES}

1. Filipe JA, Barros H, Castro-Correia J. Sports-related ocular injuries. A three-year follow-up study. Ophthalmology 1997; 104:313-8.

2. Pieramici DJ, Sternberg P Jr, Aaberg TM Sr, Bridges WZ $\mathrm{Jr}$, Capone A Jr, Cardillo JA, et al. A system for classifying mechanical injuries of the eye (globe). The Ocular Trauma Classification Group. Am J Ophthalmol 1997;123:820-31.

3. Erdurman CF, Ceylan MO, Acikel CH, Durukan HA, Mum- cuoglu T. Outcomes of vitreoretinal surgery in patients with closed-globe injury. Eur J Ophthalmol 2011;21:296-302.

4. Larrison WI, Hersh PS, Kunzweiler T, Shingleton BJ. Sportsrelated ocular trauma. Ophthalmology 1990;97:1265-9.

5. Capão Filipe JA. Soccer (football) ocular injuries: an important eye health problem. Br J Ophthalmol 2004;88:159-60.

6. Vinger PF, Capão Filipe JA. The mechanism and prevention of soccer eye injuries. Br J Ophthalmol 2004;88:167-8.

7. Reed WF, Feldman KW, Weiss AH, Tencer AF. Does soccer ball heading cause retinal bleeding? Arch Pediatr Adolesc Med 2002;156:337-40.

8. Capão Filipe JA, Rocha-Sousa A, Falcão-Reis F, CastroCorreia J. Modern sports eye injuries. Br J Ophthalmol 2003;87:1336-9.

9. Kent JS, Eidsness RB, Colleaux KM, Romanchuk KG. Indoor soccer-related eye injuries: should eye protection be mandatory? Can J Ophthalmol 2007;42:605-8.

10. Erdurman FC, Sobaci G, Acikel CH, Ceylan MO, Durukan AH, Hurmeric V. Anatomical and functional outcomes in contusion injuries of posterior segment. Eye (Lond) 2011;25:1050-6. 